(c) Trybrat T.A., Shut S.V., Borisova Z.O., Sakevych V.D., Goncharova O.O.

UDC $616.127-005.4-06$

DOI https://doi.org/10.31718/mep.2020.24.1-2.02

\title{
SOME CHARACTERISTICS OF THE COURSE OF CORONARY HEART DISEASE WITH A COMORBID PATHOLOGY
}

Trybrat T.A., Shut' S.V., Borisova Z.O., Sakevych V.D., Goncharova O.O.

Ukrainian Medical Stomatological Academy, Poltava, Ukraine

В теперішній час науковці та лікарі все більше приділяють уваги вивченню кардинальної проблеми сучасної клінічної медицини, ко- та поліморбідності, яка може виникати внаслідок спільної етіології , патогенезу, причиннонаслідкового зв'язку (синтопічні ураження), або як випадкове поєднання захворювань (супутні ураження), віковим чинником, анатомічною близькістю уражених органів або випадкове поєднання захворювань. Мета: визначити супутні захворювання та їх перебіг, які найчастіше спостерігаються у хворих на IХС. Матеріали та методи дослідження. У проспективному дослідженні взяло участь 100 хворих на IXC: стенокардію напруги стабільну, I-IV ФК, СН I-II. Результати та ї обговорення. Частота поєднаної патології у хворих на ХС зростає з віком: в I групі превалює один коморбідний стан (переважно захворювання шлунково-кишкового тракту), у II- III групі - два і більше супутніх захворювань. Серед загальної кількості хворих, 95\% проживає у місті, що є результатом урбанізаційного процесу, і лише 5\% проживають у селі. Провівши аналіз призначень хворих на ішемічну хворобу серця , кількість препаратів, яку використовують під час лікування, виявили збільшення використання більшої кількості лікарських препаратів у віковій групі III ( $\geq 60$ ) порівняно з I ( $\leq 40)$ та II (41-60). Адекватне комбіноване призначення лікарських препаратів хворим з коморбідних станами дасть можливість не тільки запобігти прогресуванню кожного з захворювань, але і поліпшити віддалений прогноз. «Лідером» серед загальної кількості коморбідних захворювань $\epsilon$ ЕАГ, яку має 77\% хворих серед загальної кількості пацієнтів, найбільша захворюваність у II (41-60) та III ( $\geq 60$ ) віковій групі. Отже, отримані результати свідчать про відмінності в перебігу та клінічній картині захворювання IXС залежно від наявності коморбідної патології , що зумовлює тяжчий перебіг захворювань, збільшенні кількості супутніх захворювань зі зростанням віку хворих.

Ключові слова: коморбідність, ішемічна хвороба серця, вік, захворюваність.

Nowadays, scientists and doctors are increasingly paying attention to the study of the cardinal problem of modern clinical medicine, comorbidity and polymorbidity, which may arise as a result of common etiology, pathogenesis, cause and effect influences (the syntopic impairments) or as an accidental combination of disease (the accompanying impairments) with age factor, anatomical closeness of the affected organs or accidental combination of diseases. The aim: to define the concomitant diseases and their course, which are most often observed in patients with CHD. The prospective study involved 100 patients with coronary heart disease: stable angina, I-IV NYHA Class, I-II HF. Results and discussion. The incidence of combined pathology in patients with CHD increases with age: in group I, one of the comorbid conditions prevails (mainly gastrointestinal tract diseases), in group II and III, there are two or more concomitant diseases. Among the total number of patients, 95\% live in the city, hence the result of the urbanization process, and only 5\% live in the village. The analysis of medicines prescriptions, used in the treatment of patients with CHD revealed an increased use of larger amounts of drugs in age group III ( $\geq 60$ ) as compared to groups I ( $\leq 40)$ and II (41-60). Adequate combined prescriptions of medicines to patients with comorbid conditions will allow us not only to prevent progression of each disease, but also to improve the long-term prognosis. Essential hypertension is the «leader» in the total number of comorbid diseases, which makes up $77 \%$ of patients among the total number of subjects, with the highest incidence in the II (41-60) and III ( $\geq 60)$ age group. Thus, the obtained results indicate differences in the course and clinical presentation of coronary heart disease, depending on the presence of comorbid pathology, which leads to a more severe disease course, a greater number of comorbidities with increasing age of patients.

Keywords: comorbidity, coronary heart disease, age, incidence.

The present study is a part of the research work of Department of Propaedeutics of Internal Medicine with Patients Care, General Practice (Family Medicine) of Ukrainian Medical Stomatological Academy «Features of the course of cardiovascular pathology in patients of different age categories, depending on the presence of components of metabolic syndrome and comorbid conditions, ways of correction of revealed disorders and prevention». State registration number $0119 U 102864$.

\section{Introduction}

Nowadays, scientists and doctors are increasingly paying attention to the study of the cardinal problem of modern clinical medicine, comorbidity and polymorbidity, which may arise as a result of common etiology, pathogenesis, cause and effect influences (the syntopic impairments) or as an accidental combination of disease (the accompanying impairments) with age factor, anatomical closeness of the affected organs or accidental combination of diseases. [1].

Polymorbidity or multimorbidity, comorbidity (from Latin: co - "together", morbus - "disease") is the presence in one patient of two or more diseases, pathogenetically interdependent or coincident in time.

Polymorbidity causes significant changes in the clas-

To cite this English version: Trybrat T.A., Shut' S.V., Borisova Z.O., Sakevych V.D., Goncharova O.O. Some characteristics of the course of coronary heart disease with a comorbid pathologY // The Medical and ecological problems. - 2020. - Vol 24, № 1-2. - P. 8-11. 
sic signs of the disease and can significantly affect their diagnosis and treatment.

According to the State Committee of Statistics of Ukraine (as of 23.01.2018), the death rate from cardiovascular diseases occupies the first place and amounts to $66.6 \%$.

Atherosclerosis is the main cause of polymorbidity in the elderly. Vascular atherosclerosis leads to the development of polymorbidity on the pathogenetic principle: coronary heart disease (CHD), dyscirculatory atherosclerotic encephalopathy, arterial hypertension $(\mathrm{AH})$, atherosclerosis of mesenteric vessels, intestinal ischemia, etc. [2]. To a large extent, this concerns a combination of arterial hypertension $(\mathrm{AH})$, coronary heart disease $(\mathrm{CHD})$, heart failure (HF), diabetes mellitus (DM), chronic obstructive pulmonary disease (COPD), obesity, kidney and liver pathology, etc.

While only a few studies on this issue were published during the 1990-2000 period, from 2001 to 2010 their number reached 39 [3]. Among patients who seek medical attention from a family doctor in the UK, more than $80 \%$ have a combined pathology [4]. Comorbid diseases and conditions can be conditionally divided into 4 groups:

- causal, if patient have $\geq 2$ diseases with one mechanism of progressing;

- complications of the underlying disease;

- competitive condition of unrelated diseases;

- intercurrent, when acute disease occurs against the background of the disease with the chronic course [5].

Thus, comorbidity includes both random combination in one patient of diseases, different in etiology, pathogenesis and nosological syntropy, i.e. progression of naturally conditioned (deterministic) combinations of diseases. Syntropy is defined as a type of polypathies, when courses of diseases develop one after another [6].

The amount of diseases has a direct correlation with age. The average number of diseases per patient hospitalized in geriatric hospital is from $5.2 \pm 1.7$ in the group of 60 65 years to $5.8 \pm 1.8$ - in the group of $81-85$ years [7] .

The risk of emergence of side effects against the background of the prescribed treatment in elderly patients is by 57 times higher, than in patients of young age, when prescribing $\geq 3$ drugs, it increases by $\geq 10$ times [8].

According to research conducted in the Netherlands, $7 \%$ of people aged $45-64$ years have $\geq 4$ diseases, at the age group $65-74$ years, the frequency rises to $30 \%$, in people aged $\geq 75$ years it is $55 \%$ [9].

According to studied by D. Campbell-Scherer (2010), the prevalence of comorbid conditions ranges from $69 \%$ in young patients, to $93 \%$ in middle-aged patients and up to $98 \%$ in elderly patients. The number of multimorbid conditions increases from $10 \%$ in patients $<19$ years to $80 \%$ in patients $\geq 80$ years [10]. The presence of concomitant pathology can lead to late diagnosis of COPD. For example, in the presence of CHD shortness of breath can be estimated only as a symptom of heart failure for a long time [11].

The features of systemic hemodynamics in patients with $\mathrm{CHD}$ combined with essential hypertension, type 2 DM are statistically significant increase in cases of insufficient decrease in blood pressure (BP) at night, compared with patients with $\mathrm{CHD}$ with $\mathrm{AH}$ without type $2 \mathrm{DM}$, which is an increased risk of cerebrovascular disease of this category of patients $[12,13]$.

Modern scientific literature actively discusses the problem of providing medical care to patients with $\mathrm{CHD}$, where an integral assessment of the state of human health is required, the prescribing of treatment taking into account the interaction of medicines, the provision of recommendations on the regime and duration of taking drugs. $[14,15,16,17]$. Standards of treatment for patients with $\mathrm{CHD}$ and $\mathrm{AH}$ or HF include $\beta$-blockers, ACE inhibitors and diuretics. It should be emphasized that, high doses of loop diuretics can cause metabolic alkalosis followed by suppression of respiratory function and it needs to be considered in patients with comorbid conditions with COPD.

Therefore, the issues of comorbidity are relevant and require extensive research.

The aim. To define the concomitant diseases and their course, which are most often observed in patients with CHD.

\section{Materials and methods}

The prospective study involved 100 patients with coronary heart disease: stable angina, I-IV NYHA Class, I-II HF.

The diagnosis of CHD according to the recommendations of the European Society of Cardiologists, Order of the Ministry of Public Health of Ukraine as of 03.07.2006 № 436 "About approval of protocols of rendering medical care" in the specialty "Cardiology", according to the Unified clinical protocol of medical care (UCPMC) "Coronary heart disease: stable angina pectoris. Primary care", according to the Order of the Ministry of Public Health of Ukraine of 23.11.2011 №816 and under the Unified Clinical Protocol of primary, secondary (specialized) and tertiary (highly specialized) medical care "Stable coronary heart disease" as of 2015.

Quantitative analysis of the results of the study and statistical processing of the data were carried out with conventional statistical methods and with the help of Excel program [18].

\section{Results and discussion}

The obtained results show differences in the course and clinical presentation of the disease depending on the concomitant pathology.

For a more objective analysis, patients were divided into three groups, according to the age. The detailed number of cases for each group and the distribution are shown in Figure 1. The frequency of combined pathology in patients with CHD increases with age: in group I, one comorbid condition prevails, in groups II - III, there are two or more concomitant diseases.

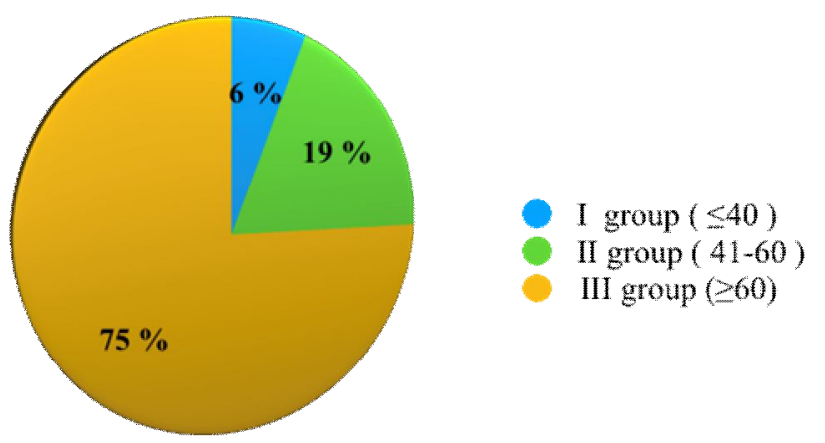

Fig. 1. Incidence of $\mathrm{CHD}$ among patients by age group

The most frequent cause of myocardial ischemia is atherosclerotic changes in the epicardial venal arteries, which cause to the narrowing of these arteries, that cause a decrease in myocardial perfusion at rest or limits the possibility of adequate growth of myocardial perfusion 
when there is a need for it [19]. Among the total number of patients, $95 \%$ live in the city, hence the result of the urbanization process, and only $5 \%$ live in the village (Fig.1)
Analyzing the amount of medicines which is used in the treatment of patients, we revealed an increase in use of medicines in age group III $(\geq 60)$ in comparison with groups I ( $\leq 40)$ and II (41-60) (Fig. 2).

100

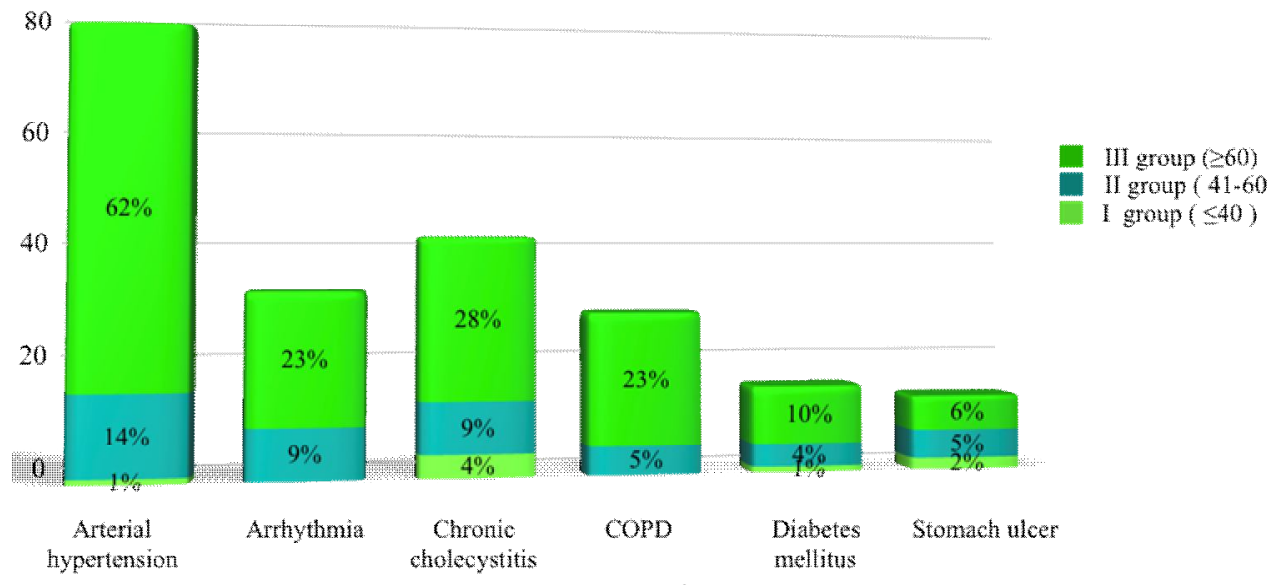

Fig.2 Total incidence rate of patients by age group

Increase in the amount of used medicines in comparison with group I $(\leq 40)$ is associated with exacerbated diseases in groups II (41-60) and III ( $\geq 60)$, as result of increase in the necessary medicines for treatment. This approach to treatment on the one hand is necessary and mandatory, but at the same time increases the toxic effect of drugs on the body of patients and the risk of side effects in patients of old age, affects both the quality of treatment of patients and their wallet, in turn it reduces the compliance of patients to treatment. Doctors need to take a meaningful approach to this clinical problem, taking into account the peculiarities of the clinical course of both CHD and comorbid condition, as well as pay attention to the tolerance and safety of medicines, even within the same class, based on the evidence base and the presence of additional pharmacological effects.

Co- and polymorbidity in CHD are diseases with localization of pathological process in other systems of organism, namely this disease of gastrointestinal tract, respiratory system, and organs involved in metabolism.

According to Figure 2, essential hypertension is the «leader» in the total number of comorbid diseases, which makes up $77 \%$ of patients among the total number of subjects, with the highest incidence in the II (41-60) and III $(\geq 60)$ age group.

One in four inhabitants of the earth after the age of 40 has increased blood pressure (BP). $\mathrm{AH}$ is the main risk factor for the progressing of chronic forms of $\mathrm{CHD}$ and myocardial infarction (MI), as well as cerebrovascular diseases (CVD), in particular brain stroke.

The high incidence among patients of groups II and III is associated with the main age changes occurring in the arterial wall of people as physiological aging this clear progressive, symmetrical thickening of the inner shell, plays no small role in essential hypertension. From a functional point of view, age changes lead to a gradual increase in vascular rigidities. Large trunk arteries can expand, increase and become winding [20].

Arrhythmia is an immediate indicator of heart damage and has the lowest frequency among patients $-32 \%$. Patients of the I $(\leq 40)$ age group have practically no comorbid pathology while this incidence prevails in the age groups II (41-60) and III ( $\geq 60)$.
$41 \%$ of patients have chronic cholecystitis, that is, virtually every second patient has this pathology, with the prevalence of morbidity in women.

Biliary dyskinesia (BD) can cause cardialgia in patients with $\mathrm{CHD}$, and the co-morbidities of the biliary system cause the progression of hemodynamics, impair the course of ischemic heart disease.

Patients with coronary artery disease and comorbid chronic non-calculous cholecystitis were characterized by compressive, burning and aching pain that occurred in the heart area simultaneously with pain in the right hypochondrium, or a few minutes after its onset. Duration of pain was from 15 to 30 minutes. The characteristic feature is the occurrence of night-time pain by the type of Prinzmetal's angina among patients of groups II-III.

$28 \%$ of patients had COPD, among whom age group III ( $\geq 60$ ) prevailed. Progression of COPD in age group III $(\geq 60)$ is associated with age changes in the structure of the respiratory system, and presence in patients' anamnesis of an addiction such as smoking. The risk factors in patients with CHD in combination with COPD included smoking (87.1\%), overweight $(65.3 \%)$ and hypodynamia $(86.0 \%)$. This comorbid pathology is characterized by a higher rate of exacerbation of CHD and COPD. COPD modifies clinical course of CHD, is accompanied by high frequency of atypical course of angina (in 59, 7\% of cases), increased frequency, duration of angiosis attack, atypical localization and irradiation.

The frequent combination of COPD and CHD may be associated with the close pathogenetic link of these two diseases. Non-specific persistent inflammation, oxidative stress and, as a result, progressing of endothelial dysfunction not only can contribute to mutual burdening of these pathologies, but also be trigger factors in their formation [20].

$15 \%$ of patients had diabetes mellitus. Most patients were in age group III ( $\geq 60$ ) with prevalence of type 2 diabetes.

In the comparative analysis of cardiological complaints, which are mainly group II and III patients pay attention to the following facts: III group of patients are $15 \%$ more likely to experience heart failures, heartbeat, which 
probably indicates about neurovegetative dystrophy in patients with DM.

In $60 \%$ of patients, except for the typical angina pains, they was pain that is more likely to be cardialgia. It localized in the region of the apex of the heart and the left subclavian area. The character of pain was more often nagging, without specific localization, prolonged (up to several hours), non-irradiated, were stopped by sedatives, not nitroglycerin intake.

The presence of these complaints significantly worsened the condition of patients in the group, and probably indicated the combination of coronary atherosclerosis with diabetic myocardial dystrophy.

It should be noted that in $10 \%$ of group III, there was a painless form of angina, in group I-II, there were no such patients.

Patients of groups II and III with psychological and emotional overstress were more likely to experience pressing pain in the heart area or behind the sternum more often than in patients of group I, whereas in patients of group I these complaints more often appeared under the influence of physical activity.

Stomach ulcer uniformly affected all age groups. The overall incidence is $12 \%$.

Patients with CHD have stomach ulcers $(60 \%)$ more frequently than duodenal ulcers, more often with localization in the small curvature and pyloric department of the stomach. Men have stomach ulcers 3 times more often than women. The tendency to painless course of stomach ulcer was noted, or the pain was localized in the left half of the chest, in most cases increased at the height of digestion, combined with chest pain. There was no seasonality of exacerbations, they most often coincided with exacerbations of CHD.

The results of the studies showed that duodenal ulcer has its own features. In group I, in patients having a nor$\mathrm{mal} / \mathrm{mild}$ course of ulcerative disease, dyspeptic syndrome prevailed among other complaints. First of all, they suffered from heartburn. Pain syndrome prevailed in patients of groups II and III long history of ulcer and in 30\% cases with severe course of the disease. Patients in these groups were significantly more likely $(p<0.05)$ to experience acute pain radiating to the right hypochondrium, as compared to patients in group I in which the pain did not spread and was dull in nature. Patients of group I with exacerbation of gastric and duodenal ulcer, had problems, associated, first of all, with dietary disorders, patients of groups II and III explained the cause of exacerbation because of stressful situations in $51 \%$ of cases.

Conclusions. Thus, the obtained results indicate differences in the course and clinical presentation of coronary heart disease, depending on the presence of comorbid pathology, which leads to a more severe disease course, a greater number of comorbidities with increasing age of patients.

\section{References}

1. Humeniuk A.F. Aspects of the rational treatment of cardiovascular patients with polymorbid lesions. Ukr. honey. Journal 2009; 5 (73): 25-34.

2. Drangoy M.G. Age-related diseases. Exmo, Moscow 2007; 738-739

3. Caughey G.E., Roughead E.E. Multimorbidity research challenges: where to go from here? Journal of Comorbidity 2011; 1: 8-9.

4. Mercer S.W., Gunn J., Wyke S. Improving the health of people with multimorbidity: the need for prospective cohort studies. J. Comorbidity, 2011;1: 4-6.

5. Van Weel C., Schellevis F.G. Comorbidity and guidelines: conflicting interests. Lancet 2006;367(9510): 550.

6. Valderas J.M., Starfield B., Sibbald B. et al. Defining Comorbidity: Implications for Understanding Health and Health Services. Ann. Fam. Med. 2009; 7 : 357-363.

7. Lazebnik LB Aging and polymorbidity. Medicine and Pharmacy News 2007; 10-11.

8. Komissarenko IA .Polymorbidity and metabolic syndrome in the elderly. Wedge. gerontology 2009; 15 (1): 29-36.

9. Dawes M. Co-morbidity: we need a guideline for each patient not a guideline for each disease. Fam. Pract. 2010; 27(1): 1-2.

10. Campbell-Scherer D. Multimorbidity: a challenge for evidence-based medicine. Evid. Based Med., 2010; 15(6): 165-166.

11. Global Initiative for Chronic Obstructive Lung Diseases (GOLD). Global strategy for diagnosis, management, and prevention of chronic obstructive pulmonary disease. NHLBI/WHO workshop report. [Electronic Resource] / WHO, 2011; http://www. goldcopd.com/

12. Shut SV, Chekalina NI, Tribrat TA, Shapovalenko N. Yu Ischemic heart disease and hypertension: features of disorders of central hemodynamics. Medicine of Transport of Ukraine 2010; 1 (33): 47-49.

13. Shut SV, Tribrat TA, Sakevich VD, Goryashchenko TI, et al. Features of the daily profile of blood pressure in patients with hypertension with metabolic syndrome. Bulletin of problems of biology and medicine 2016; 2, 1 (128): 132-134.

14. Vertkin AL, Rumyantsev MA, Scotnikov AS. Comorbidity. Clinical Medicine 2012; 10: 4-10.

15. Pichkhadze GM, Satbaeva EM. The effect of polypragmasia on the severity of adverse effects in elderly patients. Pharmacy of Kazakhstan 2014; 4: 22-23.

16. Mitrofanov IM, Nikolaev Yu, Dolgov NA, Pospelova TI. Regional features of polymobidity in the modern clinic of internal diseases. honey. 2013; 6: 26-29

17. Caughey GE. Roughead EE. Multimorbidity research challenges: where to go from here? J. of Comorbidity 2011;1: 8- 10.

18. Lapach $\mathrm{CH}$. Chubenko $\mathrm{AB}$, Babich MON. Statistical Methods in Biomedical Research Using Exel. Kiev: Morion, 2000; 320

19. Bogoslav TV, Medvedev BB. Peculiarities of vascular changes in young patients with hypertension. Ukrainian Cardiology Journal 2015; 1:28.

20. Treumova SI, Petrov EE, Burmak Yug, Ivanytska TA. Chronic obstructive pulmonary disease and coronary heart disease: problems of comorbidity (literature review). Bulletin of problems in biology and medicine. 2017; 4, 3 (141): 66-72.

Матеріал надійшов до редакції 10.01.2020. 